\title{
Ideological Commitment in Modern African Poetry: Redefining Cultural Aesthetics in Selected Poems of Niyi Osundare's The Eye of the Earth and Village Voice
}

\author{
Raphael Chukwuemeka Onyejizu \& Frances Uchenna Obi \\ Raphaelnjz@gmail.com \& Uchennammuo@gmail.com \\ Department of English Language and Literature Nnamdi Azikiwe University \& University of \\ Nigeria, Nsukka, NIGERIA
}

\begin{abstract}
In this study, ideological commitment to cultural norms is a standpoint that has led to the development of modern African poetry. The Modern African poet is seen as an advocate for cultural prowess and transformation and as such naturally adopts this African traditional antecedent in his poems. Several critical studies on the two collections have focused on the stylistic and literary values of Osundare's craft without appropriate reviews on the poet's use of cultural forms to reflect his ideological stance on pertinent issues affecting the society. The descriptive qualitative content analysis method was used to show how the selected poems reflect Homi Bhabha's postcolonial theory of hybridity as expressed through the shifting of cultural margins in the society, thus, illustrating the use of cultural art forms as a means of appreciating nature and exploring issues of exploitation and marginalization. The study also examines the influence of the traditional Yoruba African culture on the poet with an adequate focus on the content and devices of orature, proverbs, riddles, parables, humor, satire, and traditional forms of language. The study submits that the poet adequately incorporated the ideals of culture and its elements in his enduring craft showing his allegiance to his folk cultural patterns.
\end{abstract}

Article

information

Keywords: cultural aesthetics; orality; poetry; Ideological commitment

DOI: 10.24071/joll.v20i2.2579

Available at https://e-journal.usd.ac.id/index.php/JOLL/index

This work is licensed under a Creative Commons Attribution-Share Alike 4.0 International License.

\section{Introduction}

Poetry has become a tool for recounting and recreating the history and the cultural experiences of a people. It has served as a medium of interrogating the cultures of multiliterate societies, thereby, bearing the aesthetic burden of the African poet. While Van Damme (2000) sees "aesthetics" generally as a given culture's views on "beauty" or related qualities (p. 8), poets make use of aesthetic elements and art forms as a medium of expression in communicating social, political, and cultural issues. Being a cultural dependent term, its influence on African society lies in the stylistic form and technique of Modern African poetry. 
Modern African poetry as Okunoye (2004) notes is in relation to European literary traditions, which provide the paradigms, conventions, and critical principles that are either appropriated or negated in defining the identity of new literature (p. 776). This implies that the modern African poets in relation to European literature embody aspects of the African principles in the creation of African Poetry.

Modern African poets are preoccupied with cultural issues, as a means of awakening the socio-cultural consciousness of their societies, concerning various pluralist ideals of indigenous aesthetics. Such poets have resourcefully established the direction to the experimentation of poetry enriched with traditional modes and aesthetics, for artistic pontification to develop a sense of communal heritage. Thus, Ojaide (1996) notes that the modern African poetic aesthetics possesses the realities of Africans through the use of images, proverbs, indigenous rhythms, verbal tropes and the concept of space and time to establish a poetic form (p. 30).

The Modern African poet weaved his themes around the sensibilities and ethos of the African people, employing the use of varying communicative tools, techniques, and models of language peculiar to the African belief system and style of writing. Poets like Tanure Ojaide, Niyi Osundare, Masizi Kunene, and Ezenwa-Ohaeto are Afrocentric poets who have infused the dialectics and aesthetics of cultural forms in African Poetry, not only to promote the neglected and despised cultures of Africans but also to portray the sociopolitical situation in the society using traditional archetypal symbols. They use their poems to emphasize and re-echo the relationship between man and his environment, man and his fellow man and man and his gods. Their use of cultural forms was set at demystifying poetry, which brings it down to the grass-root to aid easy understanding.

In recent times, orality has featured as one of the foundations of indigenous transmission of the literary and cultural values of Africans. It has served as a wealthy resource for the Modern African poets. Through orality,
Modern African poets have engaged in the utilization of cultural resources and identity to express themselves unequivocally. This development in modern times has served as the basis for scholarly transcendence in critical discourse, and as the "creative principles that govern the form of contemporary Nigerian poetry" (Odinye, 2019).

A range of views on orality emphasizes the dualistic quality of art, sustained in writing. Ong (1930) in Orality and Literacy gives primacy to preliterate forms of a people's heritage against the backdrop of printing. His reference to literacy shows the implication of orality today. He acknowledges the immense position orality holds while lending credence to literacy, as the factor behind its emergence in print. He highlights the importance of orality to the cultures and traditions of people because, despite the advent of literacy, which gave rise to technology, orality cannot be completely eradicated.

Afolabi (1998) in Orality and Memory in African Poetry asserts that orality has a core relationship between memory and literacy because the modern African poet like the traditional griot owes a lot onto the memory and oral traditions. This is because without memory the creative artist dries up like an oasis in the desert of imagination. The poet thus combines the attributes of both the oral and written through the creative negotiation of oral elements like proverbs, riddles, parables, etc. To Vambe (2004), "the use of orality in Africa is an attempt by her writers to gain aesthetic independence from western traditions involved in the revitalization of traditional African cultural modes" (p. 36).

African poets resorted to their oral cultures to create a sense of belonging and identity against imposed Eurocentric traditions. Such poet includes Christopher Okigbo who was reputed for maintaining the culture of his/her society; Kofi Awoonor, who concerns himself with African folk traditions as suggested in the title of his collection, Rediscovery and Other Poem; Jared Angira and Okot P'Bitek, who use oral textual features to reflect the African culture through proverbs and songs. Niyi Osundare's poetry embodies various aspects of Yoruba culture and 
mythology. This is felt in the manner in which the poet weaves the Yoruba oral feature inherent in Okiri.

Through a conscious and systematic handling of the tradition of Yoruba cultural art forms, he underscores the exploitive attributes of the Post-colonial leaders. He makes use of traditional lyrical poems usually sung to the accompaniment of a traditional instrument. His poems are satirical, ironical, humorous, and bitter. His language explores artistic aspects of the African culture enlivened with graphological structures, repetition, proverbs, and capital letters for emphasis and breathspace pauses. African cultural aesthetics entail those rudiments of traditional rhetoric and philosophies evident in literary works of African heritage. They include elements of orature, language, traditional metaphors, symbols, and images. These cultural forms are in some selected poems of Niyi Osundare's The Eye of the Earth and Village Voices.

Previous studies on Osundare's Modern African aesthetic inclination have often reflected the stance of the poet as an individual endowed with the poetic ennoblements to advocate for the plights of his people/masses, their environment and effectively soothe the consciousness of his heritage from linguistic/stylistic, semiotic, materialist, literary, political and socio-cultural standpoints.

Osundare's poems significantly portray the relationship between the oppressed in Nigeria as represented by the masses and the oppressor's reactive temper towards political leadership in Village Voices. He considers his poetry a serious affair, and as such uses it as a socialist tool in eradicating unequal power structures that exist in the society. Consequently, he reaffirms his strong belief in collectivism by advocating for a balanced socio-economic atmosphere for the people.

Osundare draws extensively from the Yoruba tradition to create a unique pantheon distinct from the first generation of Nigerian poets. Some of the Yoruba oral poetic forms he used include Oriki (praise chant), Ekun Iyawo (bride chant), Ijala (Hunter's chant) etc. His poetic use of these traditional accessories ascribe to his allegiance and obligation to the African society.

Killam (2003) elaborates on Osundare's poetics by noting that, he combines the meditative with the rhetorical and displays a wide range of topics that reflects European cultural influence on his poetry as well as the abstractions of love, pride, humility, honesty, cowardice, misery and corruption. His poems address themes of corruption, poverty, bad leadership, culture and tradition, and the effects of colonialism in Africa. He is much aloof towards the practices of the Euromodernist poets who took over the legacy of Europeans concerning himself with the sociopolitical and socio-economic change in the country... his principal concern was with larger issues of Nigerian public life as it affects the society (p. 136). In other words, the poet deals with multifaceted issues of social, humanist, economic, and political discomfitures dominant in his native society distinct from the research focus, which investigates culture through hybridity.

Lending credence, Saleh (2003) submits that Osundare combines and juxtaposes the rustic and rural, the profane and the urban, the verbal and the non-verbal resources of language to produce an artistic creation of the contemporary Nigerian society and experience (p. 13). This portrays Osundare as a cultural activist who uses poetry to explore the experiences of the Nigerian society.

Similarly, Anyokwu (2011) sees Osundare as "both a mythopoet and a mythoclast universalizing his Yoruba metaphysics as an alter/native mythico-historical template" (p. 8). Anyokwu (2013) further lends credence to the notion of symbolism and sound imagery in his poem that, "Osundare's reliance on sound imagery and sound symbolism is in part informed by the prevailing artistic/literary temperament of his immediate Nigerian and African predecessors such as Wole Soyinka, Christopher Okigbo, J. P. Clark-Bekederemo, and Micheal C. J. Echeruo ...." (p. 2). Moreover, Anyaokwu (2015) in his recent study of Osundare's poem adds that in terms of voice, the poet ... loves to pride himself as a peoplepersona by presenting a public ' $\mathrm{I}$ ' which metamorphoses into 'we'. This 
Whitemanesque sense of people-persona runs through Osundare's poetry.... (p. 10).

From a stylistic viewpoint, both Aminu and Oluwagbenga (2017) in their grapholexical analysis of Village Voices submit that, "Niyi Osundare uses italicised lexical items ... stylistically it shows unfamiliar words, especially the Yoruba delicacies and earthen effigy" (p. 3). In other words, the poet projects the notion of style, examining the word functions and of the Yoruba speech that are unknown to their audiences. However, Adegoke and Adebayo (2015) investigate the poet's use of local metaphors in Village Voices. They inform of his style and affinity with his heritage, incorporating socially driven and satiric themes, which cast aspersions on man's weaknesses by the use of metaphors; "metaphors that are firmly rooted in the culture and environment of the Yoruba people to which Osundare has invited his audience or readers to the common concepts of capitalism, laziness, passing of time..." (p. 278). More so, Ilori (1986) broadly argues that Osundare details in The Eye:

an exuberant voyage of memories of a youth on earth pilgrimage, discovering anew away from the encumbrances of his Western education - the soul of his own society. The pilgrimage is a dramatic performance of webbed metaphors and idioms. The characters are earth's essences (rocks, rivers, rain, harvest, and drought) clothed in plural symbols. Because it derives from all of this, the language is venous, expanding into myths, riddles, puns, hyperbole, and humor. Ceaselessly, Osundare invents a tapestry of words wombed in the active life-force society (p. 1).

Ilori's view differs from Aminu and Oluwagbenga (2017) as their assessment of Osundare's work focuses on his style, while ilori concentrates on the evocative educational experience of the poet whose influence in foreign land shaped the literary direction and endow of his craft. Dare (2005) examines the presence of sex organs and sexual dictions in the poet's choice of words that are taboo and sensitive in public places. He notes that, "Osundare uses words and expressions that are severely tabooed in public discourse.
Examples are: penis, cunt (virgina), testicles, hips, orgasm, and breasts. (p. 3). This implies that the lexical-based investigation into his craft is without elements of vulgarized word usage as sensitive as it affects human sensual perception. Nwagbara (2013) veers away from Dare's view. He informs about the poet's main concern as reviving and resuscitating the natural environment, especially in The Eye, where "the reconstruction of Nigeria's natural world, which faces despoliation and commodification, including a call to save the earth from inept practice that inheres in (global) capitalism" (p. 197), calls for serious national and world concern.

Similarly, Diala (2006) corroborates Nwagbara's standpoint that the turning point in The Eye, rests in the illustration of a fresh but new theoretical philosophy of the cyclical nature of history that contrasts with the postcolonial state (p. 385). He further posits that the poet's culture creates a lasting influence in his enduring crafts and helps to understand its influence in postcolonial African literary discourse:

In varying ways, Osundare's indigenous culture has provided models he appropriates in responding to the many legacies of colonialism, especially in his conception of and in confronting the aberrations of the postcolonial state ( $\mathrm{p}$. 385).

Diala's view is very significant to this research as it helps envisage the establishment of a debatable but critical direction and inquiry into the study of postcolonial hybridity and cultural criticism, particularly in the chosen collections of poetry many more which have not been studied.

Bamigboye (2019) argues generally (in the light of his collections) that "although a lot has been written about the literary style and content in Osundare's poems, the consistent nature and size of his literary output nevertheless place him in a conspicuous position not to be ignored by curious scholars in the field of stylistics and literary criticism"(p. 1018). Nevertheless, Bodunde (1997) explores the materialist vision encapsulated in Osundare's craft, The Eye. In 
his view, he argues against the romantic convention inherent in the poems that, "... Osundare's depiction of nature, symbolized in the metaphor of earth, departs from the Romantic interpretation. Embodied in the typical Romantic epiphanic naturism is nature's capacity to communicate to human instinct and hence provoke meditation" (p. 82).

Ultimately, Doki (2009) submits that, "Osundare is concerned both with reality and the connection between the individual and environment" (p. 68). Thus, Osundare's poetry, therefore, richly embodies certain traditional oral expressions, which reflects the worldview of the Yoruba people and the environment.

Arguably, Osundare's poems adumbrate the traditional lore and indigenousness of the rural/rustic heritage of the agrarian people, who speak clearly without blemish. He uses the rural and rustic linguistic paradigms in his collection to depict the idea of poetry that embodies all aspects of the individual character. He makes use of the form, style, themes, and language of his immediate society to convey his message. Thus, from humanist, ecological and stylistic perspectives, the physical environment, man, nature, and local language resources all appear to have enhanced the overall form and content of his poetry. The review of scholarship shows that there is a need to investigate the cultural aesthetic aspect of Osundare's poems from the perspective of postcolonial hybridity, which has not been explored by any researcher.

\section{Methodology}

This study was by means of the descriptive qualitative method (Miles, Hubman, and Saldana, 2014). The choice of works was in response to the topic of research. The works have a study population of two carefully chosen poetry collections. The procedure for data collection for this study is by library material: scholarly textbooks, journals, conference papers, and printed mass media. For data analysis, the study also adopts the analytical and critical method in interpreting and analyzing the selected poems.
Ashcroft, Griffiths, and Tiffin (1995) describe the postcolonial theory as one involving migration, slavery, suppression, resistance, race, gender, place, problems of global culture, and the relationships between cultures and global forces preceding colonization (p. 2). This colonization process ultimately affects the subalterns with its act of marginalization and oppression. Postcolonialism thus creates an avenue for the oppressed to have a voice by reproducing discourses of exploitation and equating the imbalanced binary relationship between 'Them' and 'Us.'

For postcolonialism, culture is a focal point of reference. It stands at the forefront of literary discourse, bringing to limelight new interpretative perspectives of literature from a cultural dimension. Young (1995) affirms that it plays a unique role in the growing cultural discourse of contemporary political, social, and historical analysis of a people (p. 7). Culture is a significant factor that defines this literary theory, as well as an essential point that distinguishes postcolonialism from its predecessors (imperialism, colonialism, and neocolonialism). According to the post colonialists, it may be easy to break away from the colonialists politically and economically, but it is extremely challenging to neglect the significant control of culture on the colonizers. Thus, the need for decolonization may become urgent.

In postcolonial discourse, the idea of culture cannot be discussed without recourse to hybridity, which is of utmost significance to this research. The term 'hybridity' has become one of the recurring ideas in Postcolonial cultural criticism. Hybridity is a cross between two separate races or cultures. In this discussion, hybridity studies the effect of the mixture upon identity and culture.

Raj (2014)notes that:

Hybridity is a cultural transactive creating a temporal interactive sequential between the colonizer and the colonized bestowing a conciliation inestimably concussive beyond the managed identity of the dominant. (p. 125) 
Hoogvelt (1997) corroborates this view that hybridity gives room for "a kind of superior cultural intelligence owing to the advantage of in-betweenness, straddling of two cultures and the consequent ability to negotiate the differences" (p. 158). Raj further clarifies that hybridity emerges in the context where the colonial authority attempts to transform the identity of the other compassing within a "singular universal framework" but unsuccessful in his endeavor eventually fabricating something new but familiar ( $p$. 125). Indeed, hybridity would permit the "creation of new transcultural forms within the contact zones produced by colonization" (Ashcroft et al. p. 20).

Bhabha (1996) describes the shifting of margins in the significance of cultures, which illustrates how individuals acquire value systems and norms of other societies. In reality, all cultures turn out to be hybrid, through this; the characters can accommodate the value systems of a particular diverse society culturally, politically, socially, and otherwise.

This study, however, uses the Postcolonial theory of hybridity, to illustrate the use of cultural art forms as a means of identity in poetry to include orature, language, traditional images and symbols and cultural concerns of hybridity and communalism, as a means of exposing issues of oppression, subjugation and cultural assimilation in the society. In other words, the contextualization of hybridity in the African scenario may be based on the language resources and devices altered to suit the local setting; that is, "to take the European language to suit it to the African surrounding" (Emenyonu, 1991).

\section{Results and Discussion}

The Eye of the Earth and Village Voices are unique in their perception of man, his environment, and natural elements. Osundare celebrates the tradition and culture of his people with the maximum focus on nature. Alu (2008) describes The Eyes of the Earth as "one which celebrates the work of the culture of a people with special emphasis on the reverence of nature" (p. 70)
More so, Addo (2015) remarks that, The Eye of the Earth "presents various themes ranging from the threat to the earth by man's irresponsible actions to the celebration of the earth as a repository of wealth and inspiration" (p. 28).

Ngumha (2011) adds that:

Osundare, in The Eye of the Earth assumes the role of shamanic rainmaker not only for the material good of the planting and foodgrowing ikere community but also for the symbolic salubrious enrichment of the citizens of the universe whose ultimate well-being depends on the fertility of the earth (p. 126)

His use of the African oral tradition projects the African modern experiences in its unadulterated form. Osundare made use of certain features of cultural aesthetics like orality, which exploits the use of proverbs, riddles, and performance, the figurative use of language, idiomatic expression, images, symbols, rhetoric, praise names, songs, and chants signifying the rich heritage of the Yoruba people.

The thematic range of Yoruba culture and the preoccupation of the poor and downtrodden may fall within the collections Villages Voices and The Eye of the Earth. While The Eye of the Earth is reflective of nature and other physical components of the earth, Village Voices expresses concern over the exploitation and uneven distribution of resources by the leaders.

About Osundare's poems, Elgeezeery (2013) notes that, "he employs the oral Yoruba traditions to widen the scope of Nigerian poetry readership" (p. 62). Ultimately, Osundare (2005) declares in My Poetry posits thus, "My poetry is strongly influenced by Yoruba poetics. Mine is a figured fancy, Metaphor, Simile, hyperbole, metonymy and other figures of speech populate the lines as fishes do a fertile river" (p. 55)

In "The Rocks Rose to Meet Me," the persona who is a returnee to his homeland after a long time presents an image of two powerful kings in the guise of "Olosunta" and 
"Oroole" as two imposing rocks, which rose from their thrones to welcome him into their presence. The poet stands before the rock just like Okigbo stood at heaven's gate before mother idoto. The poet says:

You have been long, very long and far Unwearying wayfarer, Your feet wear the mud of distant waters Your hems gather the bur of the farthest forests (p. 13)

The poet celebrates the rock of Olosunta, which is worshipped by the people of his hometown, especially during the Olosunta festival. His description of Olosunta as the "lofty one whose eyes are/balls of winking sun" (line 9,10), lends credence to the fusion of figurative elements used to define his craft. More so, the reverence and esteemed status of Olosunta as depicted in his craft substantiates our claims to orality:

The rocks rose to meet me

Like passionate lovers on a long-awaited tryst

Their peaks cradled in angel's mists (p. 13)

By celebrating the rock of his town, Osundare is not only re-enacting the love of nature and the wealth it brings to the Ikere people of Ekiti State but also, projecting the rich cultural heritage of his people to the world.

Osundare's cultural commitment is prominent in his profound use of poetic epithets, which are literary devices usually indicative of the artistic and formulaic language of oral poetry, which help in the proper handling of the oral thought process. An illustration of this poetic epithet below:

Palm bound, scalp-toothed

The squirrel pierces the tasty iris

of stubborn nuts;

Probers; those who marvel

the canine fire in your mouth

let them seek refuge

in the fluffy grace of your restless tail (p.14)

"The Rock Rose to Meet Me" is a homecoming kind of a journey back and forth into a receding past. The rock celebrated,
"Oroole," is a sibling of Esiade; it occupies a central place in the cosmic consciousness of Ikere people. With thunderous drumming and dancing, the rocks are worshipped and frequently and appeased with rare gifts. The poet, by celebrating the rocks in his hometown, displays his love for natural resources.

In "Forest Echoes", the poet uses the "Oriki" praise chants as a tribute to the earth. The Okiri, as Ayinde (2012) notes, "goes beyond mere praises and is a good source of history" (p. 89). The praises in honor of the earth reinforce the concept of orality. The forest trees like the tough Iroko (Oganwo) and Ayunre get much praises according to their strength and fruitfulness.

The poet further talks about the forest of Ubo Abusoro where he recounts good old memories depicting the progressive condition of the forest. Now he laments bitterly about the wanton destruction of economic trees. The natural elements form part of the rhetorical account in his poem. He describes the palmwine tree as a conqueror of rainless seasons/mother of nuts and kernel/bearer of wine and life:

\section{This is Oke Ubo Abusoro \\ The distant forest, which shames the lazy leg \\ Where the oro tree hawks lofty fruits \\ This is Ubo Abusoro \\ Where my first faltering steps \\ Broke the earthworm on the part of dawn (p. 5)}

Odinye (2019) envisages that the poet's intentional use of the Yoruba name for these trees, Iroko, Oganwo, and Ayunre depicts the traditional consciousness of Africans to explore our cultural beliefs in literary works. Osundare further praises the forest trees saying:
Iroko wears the crown of the forest Town's rafter, roof of the forest
Oganwa wears the surrogate crown of height and depts.
Oh Ayunre
Feather tree of the forest (p. 6) 
In "The Rocks Meet Me," the poet also uses the praise epithets by showering praises on the rocks. This was intended to make poetry appeal to his local African audience. An example of a local riddle in the poem goes thus: "But how to dig the gold/without breaking...." (line 16). Osundare also made use of praise names and wise sayings as perpetuated in Yoruba communities especially by elders. This use of wise sayings here is to buttress an idea of wasted labor. The poet made copious use of allusions to 'Olosunta' rock in Ikere, Ekiti state. He personifies the rocks in the poem.

Osundare uses these praise techniques in his poems as an outstanding indication of the African ideological consciousness and cultural forms evident in their way of life. Hence, his reference to earth, trees, gods, person, and place in his poetry symbolizes the beauty of the Yoruba culture.

African mythic ideation of the first rain being an instrument for purification of the land from evils, meet apt portrayal in the "First Rain". In this poem, the poet expresses his joy that the rainfall would make the earth "breath again".

When the first rain has just clipped
the wing of the huge dust
a cooling warmth embraces
our searching soles
as the land vapour rises
like a bootless
Infantry
And through her liberated poles
Our ear breathes again (p. 29)

In Village Voices, the poem "The Brides Song" reflects the significance of traditional values and morals instilled in the African child. The bride praises 'Baba' a symbol of father for the upbringing she received and therefore, promises to be a virtuous woman.

\section{Baba, thank you today}

For the kindness of many years

Gone I am now to my husband

The son of Efuruowo whose ground

Owner of the powerful machete (p. 42)

In Village Voices, Osundare makes use of proverbs in the poem "Akintunde Come
Home". He admonishes Akintunde to come home to behold the deplorable state of things in his home.

Akintunde, come for though a man's

Penis is small he will not borrow a bigger one

To fill up his wife's nagging mouth (p. 3)

In "Advice", the poet uses images drawn from the African culture to inform people about the consequences of telling lies. The illustration of yam and farmer describes the fraudulence of the farmer and the politicians, who make phony promises and pillage public funds.

In "Land of Unease", Osundare uses the lopsided nature of the five fingers to show the irregular distribution of resources. $\mathrm{He}$ laments:

\section{The land never knows peace \\ Where a few have much \\ And many none at all (p. 45)}

Performances are products of orature, whose portrayal meet the rhythm of music and drumbeat. Osundare directs that the poem "The rock rose to meet me" should be chanted with 'Agba drum' (traditional drum usually made from the hide and skin of animals) throbbing in the background. The poet shows interest in oral performance poetry with instruments for its orchestration. The "Rain Songs" in the collection are highly lyrical, interspersing with musical aids such as the flute, and rain drum

In "Let Earth's Pain Be Soothed", Osundare evokes a world of plunder and destruction of the earth and its resources. Nature is angry with the man for his destruction of the earth and as a result, the skies refused to send down rain. This brings about drought, hunger, and starvation.

Through his use of language, Osundare, demystified language using the cultural inclinations of the Yoruba people so that everyone can easily understand meanings. The technique employed by him is the use of the literary traditional motif to produce the common person's poetry. Chuma-Udeh (2011) 
asserts that the "common man's poetry is aimed at totally demystifying poetry and bringing it to the level of the grass-root...they write in the language the common man understands" (p. 100).

Poets like Osundare, write for the common man by embellishing stories, narratives and realities of the people with oral traditional technique to make poetry not just accessible but also comprehensible. The use of metaphorical phrases laced with traditional symbols is evident in the poem, "Forest Echoes". The trees Iroko and Ayunre were personified with the various roles they carry out in the forest.

\section{Let Iroko wear the crown of the of} Let Ayunre play the clown of the fireplace But let no tree challenge the palm mother of nuts and kernels (p. 7)

The traditional symbol of mortar and pestle illustrating a bountiful harvest that accompanies the abundance of food is depicted in "Harvest Call". The wooden form of Mortar and pestle used in traditional African society to pound, engage in a simultaneous tussle that leads to the production of food. The poet says:

The pestle fights the mortar

The mortar fights the pestle

A dough of contentious smoothed down

The rugged anger of hunger (p. 18)

The poem "Let It Rain" illustrates the use of refrains, repetition of phrases, lines, and structures to reference the lyrical tone of the song. Thus, the sky carries a boil of anguish/let it burst/let it rain (Lines 1, 2 and 16). This is employed for rhythmic and lyrical effect. The refrain "Let it rain" is used to reinforce the lyrical tone of the songs employed in the poem. The repetitive use of the chorus is evident in a cultural setting, an indication of emphasis. The poet also made use of proverbial saying like "that parched throats may heal her silence/ That corn leaves may clothe the hills."

In the poem, "Let earth pain be soothed" the title shows that earth is personified as an individual who undergoes a period of pain, but with the arrival of the rain, the pains become soothing. There are a series of personification used in the poem: "the sky carries a boil of anguish/clouds journey over trees/cradle of green/the earth may heal." Besides, an example of hyperbole/exaggeration is, "the sky carries a boil of anguish," while an example of simile reads, "A prostrate like famished horses." Other features that portray the poet's ideological commitment to culture are portrayed in the use of traditional grammatical parallelisms, similes, metaphor as well as indigenous features of drums; dancing feet, and melody fully portraying the African culture.

Cultural concerns in the poems under analysis typically involve issues of hybridity relative to local language devices, communalism, and the historical consciousness of his African society. The poet writes to uplift the suppressed African culture by colonial conquest. He makes use of hybridity, which highlights the juxtaposition of two cultures in terms of language resources, thereby, revealing the influence of one culture over the other. His apt use of witty aphorisms and traditional Yoruba phrases to create highly potent poetry accentuates this discursive claim to hybridity. Osundare also depicts the hybridized nature of some African values which are not truly rooted in the African culture neither are they truly rooted in the European culture. He acknowledges the fact that most Africans living in diaspora are culturally displaced and hence needs reorientation and re-adjustments. This, he represents, in the poem "The Rock Rose to Meet Me," where the persona stands aloof and distant from the culture of his people. The persona is depicted as a sojourner who has traveled to many countries and has finally returned home before the rock to worship it in a rendition of praise during the Olosunta festival. This reverence for the rock shows his commitment and allegiance to his root. The poetic persona as a hybrid of both European and African artistic essence, thus:

\section{Your feet wear the mud of distance waters Your hems gather the bur offarthest forest (p. 14)}

These lines show the distant nature of the returnee as every part of his body is almost certainly unidentifiable, bringing the nature of 
his identity into question. Similarly, in Village Voices the poem "Akintunde Come Home" presents a prodigal son who requires reconciliation with his home because his community needs his presence to bring them out of hunger, exploitation, and ruin:

\section{Come back here \\ Where the walls are mud \\ And meatless meat quiet \\ The howling stomach (p. 4)}

Akintunde's devotion to his immediate community is tested by the sudden call from his ancestral home. He is portrayed as a hybrid whose cultural identity is uncertain because he voyaged to other countries. Hybridity, however, may reflect the mixture of traditional African language; riddles, and proverbs with the English language. Osundare made vivid use of hybridized language in the poem. Besides, the foreseen expression is written in the English language but with a traditional riddlelike creation symbolizing Africaness:

\section{Olosunta spoke first}

The eloquent one

Whose mouth is the talking house of Ivory

Olosunta spoke first

Oroole came next (p. 13-14)

In "Let Earth's Pain be Soothed," Osundare employs abundant use of proverbs and riddles side-by-side with the European language. He expresses his themes of hunger, starvation, and thought in proverbial language:

Our earth has never lingered so dry

In the season of failing showers

Clouds journey over trees and ore hills

Misery with their liquid treasure

(p. 28)

By this rendition, the poet portrays the extent of dryness of the land, which comes as a surprise. This dryness in a season where the rain should have poured forth is interpreted as misery. He juxtaposes that with a refrain that, "the sky carries a boil of anguish/let it burst" (Line 1 and 2). Subsequently, Osundare hybridizes the European and the African culture by mixing traditional contents with Western language in "Forest Echoes":
This is Oke Ubo Abusoro,

The distant forest which shames the lazy leg

Where the oro tree hawks lofty fruits (p. 5)

The poet also uses an admixture of the African proverb with western lingual codes. Thus:

\section{Those who marvel the canine fire \\ In your mouth \\ Let them seek refuge in the fluffy grace \\ Ofyour restless tail (p. 15)}

From the foregoing, it could be seen that the poet made use of the African traditional style of writing influenced by orature and still created a perfect hybrid with both European and African forms of expression.

An intriguing aspect of the cultural inclination in Osundare's work is the idea of communalism. Osundare demonstrates that culture is communal and not individualistic because a member of the society cannot exist without the other. Hence, community harmony is felt in the collective response in the poetic rendition through chants and drumbeats. This communal heritage is evident in the interweaving of language, especially in the pronoun 'they' and 'our'. Members of the society bear the burden bestowed on them in unison; they share the same passion and pain together as it pertains to the state of the community.

The stylistic effect of Osundare's poetry is evident in the use of graphological structures, repetitions, and breath-space pauses common in oral performances. The poet also employs the use of rhetorical questions, traditional Yoruba names, axioms, the Nigerian Pidgin English, all emphasizing his love and allegiance to his cultural identity. The form of his poems is traditional, wealthy, and inventive.

\section{Conclusion}

Our analysis of some selected poems of Osundare reveals the artist as committed to the psychological, political, social exigencies of his people and their cultural milieu. With his dedication to upholding the right ideals of his society, he has chosen to be the mouthpiece of many silent voices, speaking boldly against 
various vices inherent in the society. Through his humanist and socialist models, he utilizes various traditional artistic elements by appropriating the lyrical qualities of traditional African verbal art. He combines humor, satire, and traditional aspects of language artistically reproducing and recreating a poetry that accentuates the culture of the Yoruba people; that is, the blending of the Yoruba 'stylo-syntactic' idioms and verbiage with the official structure of the English speech. This paper, therefore, makes a recommendation for further research in the area of cultural criticism, national consciousness, and Afrocentrism.

\section{References}

Adegoke, T. J. \& Adebayo, T. A. (2005) "Motivated Local Metaphors in Niyi Osundare's Village Voices: A Stylistic Analysis Perspective" Journal of School of Languages, Adeyemi University of Education.

Addo, N.E. (2015) "Analysis of Selected and Sensual Imagery as Vehicle for the messages in Niyi Osundare's Nature poems in The Eye of the Earth" International Journal of Multidisciplinary Academic Research. 3(1).

Afolabi, N. (1998) "Can the Poet make a Griot? Orality and Memory in African Poetry" Griot, 17 (2), 20-34.

Alu, N. (2008) "Style and the New Poetic Revolution in Niyi Osundare's Poetry" An International Multi-Disciplinary Journal, 2 (3), 62-84.

Aminu, S. \& Oluwagbenga, S. (2017) "GraphoLexical Features in Selected poems in Niyi Osundare's Village Voices" Asian Research Journal of Arts and Social Studies. 3(3), 17.
Anyaokwu, C. (2011) Osundare's Poetry and the Yoruba Worldview. 13(1), 1-8, https://doi.org/10.7771/1481$\underline{4374.1707}$

Anyaokwu, C. (2015) "The Essentials of Niyi Osundare's poetry" TRANSNATIONAL LITERATURE. 8(1) November. http://fhrc. flinders.deu.au/transnational/home/.ht $\mathrm{ml}$

Anyokwu, C. (2013) "Sound Semiotics of Osundare's Poetry." clcweb: comparative literature and culture 15(1), https://doi. org/10.7771/1481-4374.1994

Ashcroft, B. Griffiths, G \& Tiffin, H. Eds., (1995). The Post-Colonial Studies Reader, 2nd Edition, Routledge.

Ashcroft, B. Griffiths, G \& Tiffin, H. Eds (1998) Key Concepts in Postcolonial Studies. London: Rutledge.

Anyinde, A. (2012) "Oriki as Source of Yoruba History" A Journal of Contemporary Research. 9(2), 89-96.

Bamigboye, O. (2019) “A Stylistic Reading of Selected Poems of Niyi Osundare's A City without Poeple" Theory and Practice in Language Studies, 9(9), 1081-1087.

Biodun, C. (1997) "Niyi Osundare and the Materialist Vision: A Study of The Eye of the Earth": Ufahamu: A Journal of African Studies.

Bhabha, H. (1996) "Unsatisfied Notes on Vernacular Cosmopolitanism". In Laura Gracia-Moreno, L, Peter, C. and Pfeiffer, S.C. Eds. Text and Nation: CrossDisciplinary Essays on Cultural and National Identities, Columbia: Camden House, 191-207.

Chuma-Udeh, N. (2007) Trends and Issues in Nigerian Poetry, Base 5 Press.

Dare, A. S. (2005) "Sexual Discourse in Niyi Osundare's Poetry: A Sociolinguistic Reading" African Study Monographs, 26(2), 89-97. 
Diala, I. (2006) "Burden of the Visionary Artist: Niyi Osundare's Poetry" Contemporary Literature. 57(3).

Doki, G. J. (2009) "The Eye of the Earth: Niyi Osundare as a Poet of Nature" African Research Review. 3(2).

Elegezeery, A. M. G. (2013) "Memory and Homecoming in Niyi Osundare's The Eye of the Earth" English Language and Literature Studies. 3(2).

Emenyonu, E. N. (1991). "African Literature Revisited" Emenyonu (ed). Studies in the Nigerian Novel. Ibadan: Heinemann. 1-11.

Hoogvelt, A. (1997) Globalization and the Postcolonial World: The New Political Economy of Development. Baltimore: John Hopkins University Press.

Ilori, A. K. (1986) “Word-Robes': A Symbolic Inference of the Despoliation of Earth's Resource" Book Review.

Killam, G. D. (2003) "Osundare and Poetry for the People" in Na' Allah, R. (ed) The People's Poet: Emerging Perspectives on Niyi Osundare. Trenton: African World Press, 133-139.

Miles, M. B., Huberman, A. M., \& Saldana, J. (2014). Qualitative data analysis: A methods sourcebook. $3^{\text {rd }} \mathrm{Ed}$. Thousand Oaks, CA: Sage.

Ngumha, E. (2011) "The poet as rainmaker: Fertility and Pluvial aesthetics in Osundare's The Eye of the Earth. TYDSKRIF VIR LETTERKUNDE. 48(1).

Odinye, I. (2019) "Influence of Yoruba Concepts and Worldview in Niyi Osundare's The Eye of the Earth" Interdisciplinary Journal of African and Asian Studies, 1(1), 1-10.

Ohaeto, E. (1998) Contemporary Nigerian Poetry and the Poetics of Orality, Bayreuth University, Germany.

Ong, W. (1930) Orality and Literacy: The Technology of the World, Routledge.
Ojaide, T. (1996) Poetic Imagination in Black Africa, Academic Press.

Osundare, N. (1986) The Eye of the Earth. Heinemann.

Osundare, N. (1983) Village Voices. Evans Brothers.

Osundare, N. (2005) My Poetry is Influenced by Yoruba Poetics. Guardian, 10 July.

Okunoye, O. (2004) The Critical Reception of Modern African Poetry, Cahiers d'etudes Africaines: 769-791.

Raj, E. P. P. (2014) "Postcolonial Literature, Hybridity and Culture" International Journal of Humanities \& Social Science Studies. 1(II).

Saleh, A. (2003) Poet of the Peoples Republic: Reading the Poetry of Niyi Osundare, Benchmark Publishers Ltd.

Uzoechi, N. (2013) "Nature in the Balance: The Codification of the Environment in Niyi Osundare's The Eye of the Earth" Nordic Journal of African Studies. 22(3), 196-212.

Van Damme, W. (2000) African Verbal Arts and the Study of African Visual Aesthetics. Research in African Literatures, 31(4), 820.

Vambe, M. (2004) Orality and Cultural Identities in Zimbabwe. Mambo Press.

Young, R. C. (1995) Colonial Desire: Hybridity in Theory Culture and Race. Rutledge: London. 